\title{
The Influence of Teachers' Education Qualifications on Teacher Attrition in Public Secondary Schools of Kilimanjaro and Manyara Regions, Tanzania
}

\author{
Rashid A. Chikoyo $^{1} \quad$ Gabriel K. Nzalayaimisi ${ }^{2} \quad$ Godfrey G. Telli ${ }^{3}$ \\ 1.Moshi Cooperative University. P.O. Box 474, Moshi, TANZANIA \\ 2.Sokoine University of Agriculture. P.O Box 3004, Morogoro, TANZANIA \\ 3.Twaweza, East Africa. P.O Box 38342, Dar Es Salaam, TANZANIA
}

\begin{abstract}
Teacher education qualifications give a teacher authority to teach at different education levels. Education qualifications on teacher attrition affect labour stability in educational institutions. The purpose of the paper was to assess the influence of education qualifications on teacher attrition in public secondary schools in Kilimanjaro and Manyara Regions. Specifically, the study aimed to examine the influence of teacher's education qualification and teacher's training entry qualification on teacher attrition. The study was based on Maslow's and Herzberg's two factors theory. The study was conducted in three districts of Kilimanjaro and Manyara Regions. The study adopted cross sectional research design. The sample size for the study was 140 respondents. The study adopted simple random and snowball sampling. Data collection instrument involved questionnaires administration, and telephone interview. Quantitative data were analysed using descriptive statistics and binary logistic regression. Qualitative data were thematically analyzed. The study found that bachelor degree education qualification had statistically significant influence on attrition $\mathrm{P}<0.05$. The influence of teacher training entry qualification found slightly statistical significant with $\mathrm{P}<0.05$. The study concluded that the mean score for both categories of teachers were above 50 percent indicating that teacher education qualifications and teacher's training entry qualification influence teacher attrition. The study recommends to the Presidents' Office Regional Administration and Local Government to set standards on student teacher training entry qualification to all teachers training institutions and or colleges, regardless of the institution's ownership. Educational Policy makers should assure that teaching staff that need to pursue further education must be at their working stations for a specified number of years after finishing their study. Also, the Ministry of Education, Science and Technology should provide guidelines for teachers who have undergone teacher's education courses before venturing into the teaching profession.
\end{abstract}

Keywords: Teachers' education qualifications, Teachers' training entry qualification, teacher attrition.

DOI: $10.7176 / \mathrm{JEP} / 10-33-08$

Publication date: November $30^{\text {th }} 2019$

\section{Introduction}

Globally, teachers' education qualifications have great impact on student achievement in schools where education qualifications for teaching secondary school levels differ from one country to another (Ingersoll et al., 2014; Voluntary Service Organization, 2007). Teacher's education qualifications give teachers authority to teach at different levels of education and grades in pre-schools, primary and secondary education in different countries. Education qualification is among the fundamentals for academic professional that enables a person to become registered as a teacher in teaching professionalism (Salahu and Aminu, 2010).

According to Asare et al. (2012), all children need teachers that are well trained, motivated, who can ensure that all children are learning particularly at the basic education level and staffed with qualified teachers, Similarly, provision of teachers with teaching-learning incentives and policies that would both motivate and retain them in their jobs. The current awareness on the importance of education sector for national development has globally expanded and become one of the greatest social services of the time (Salahu and Aminu, 2010). According to Salahu and Aminu (2010) the rapid growth in education can be seen practically in ever-multiplying schools, student's enrolment and the increasing number of teaching staff in different school levels.

The importance of qualified teachers in the teaching profession has become noticeable in control of teacher attrition (Preston, 2000). Many qualified and experienced teachers quit the teaching profession and job after a short period with various reasons. Teachers' education qualification might have a great influence on teacher's attrition where education qualification becomes a factor for employee decision to stay or to quit teaching (Huling-Austin, 2006; Lambert, 2004).

Teachers' attrition means shifting of labour in and out of an education system of which it is a component of teacher turnover (Loock et al., 2006; Darling-Hammond, 2003). According to Ingersoll and Strong (2011), teacher attrition is taken to mean teachers who leave the teaching career to take up other jobs. In this study teacher attrition is considered to include all teachers who leave the classroom and do not continue teaching, 
whether for short or long periods of time regardless of the reasons behind it.

This movement is a handicap for schools academic performance because it leads to the reduction in skills and efficiency in schools. Croasmum et al. (2007); Koontz and Weihnrich (2005) argue that stable organizations are characterized by low employee attrition rate and abilities to retain their customers and employees. This can only be attained if the organizational roles and the entire process of leadership are based on management, a practice that enriches the job satisfaction and motivation of the employee to stay in the job, otherwise, they quit.

Teacher attrition is regarded by scholars as an influence of important determinant factors caused by lack of education qualification which is a result of ineffectiveness, low performance, escapism caused by rise on teacher student ratio and overcrowded classrooms (Ingersoll et al., 2014; Croasmum et al., 2007) or lack of quality in contemporary education (Hahs- Vaughn and Scherff, 2008).

In the United States of America research shows that teacher education qualification varies by state: the teacher qualification and mastering of the core courses becomes fundamental in curbing teacher attrition. However, the normal bachelor's degree with a major in their certifiable area (science, math, etc.) is a minimum requirement (Hobson et al., 2014). This is done along with rigorous coursework in pedagogical methods and practical field experiences as student teachers (United States of America Departmental of Education, 2012).

On the other hand, the studies done in England indicated that teachers in the maintained sector must have gained Qualified Teacher Status (QTS) and be registered with the General Teaching Council for England (GTCE) (Hobson et al., 2014). To become a teacher a person must have completed a first degree and then a Postgraduate Certificate in Education (PCE). All qualified teachers must serve, after training, a statutory one year induction period that must be passed in order to remain a registered teacher. These education qualification prerequisites enable the teacher to remain in their teaching professions.

In some countries of Sub Sahara Africa education plans have been addressed to improve teaching quality by setting higher qualification standards for teachers (Muhammad and Maka, 2015). Ghana in particular, Diploma in Education (Dip-Ed) replaced a three year Certificate with a new structure that requires pre-service students to spend their last year of training on practical teaching attachment in schools; this provides trainees with hands-on experience in professional teaching (Wilson et al., 2014).

Similarly, Senegal, following the reform of its teacher education in 2010, the government extended the duration of pre-service training from six to nine months, stopped the recruitment of volunteer teachers and insisted on the college bachelor's degree and diploma as minimum qualification for candidates (Muhammad and Maka, 2015; Wang and Odell, 2002). This qualification is similarly practiced in Tanzania, though teachers who hold Master Degree in education are also authorized to teach in secondary schools.

In Tanzania, teaching qualifications for secondary education are Diploma in Education (Dip-Ed), Bachelor in Education (BA-Ed), Postgraduate Diploma in Education (PGD-Ed) and Master in Education (MA-Ed) which is most commonly provided by Higher Education Institutions (MoEVT, 2009). The basic education qualifications for secondary schools teachers' in Tanzania are holder of diploma and or bachelor in education.

However, different upgrading Programmes have been undertaken in order to improve the general quality of basic education in terms of improving teachers' proficiency for capacity building to retain teachers (Hardman, 2009; World Bank Education Reforms, 2007; Voluntary Service Organization (2007). This program includes; inservice training in competence based teaching methodology and licensed teacher in 2006. Yet, teacher attrition rates become noticeable in public secondary schools in Tanzania. Teachers leave the teaching post to seek careers within and outside education sector resulting in loss of qualified teachers that would be potential in raising student performance.

Literature, specifically in addressing teachers' education qualifications and teacher training entry qualification on teacher attrition in public secondary schools in Tanzania is scanty. The available studies provide little information that addresses how teachers' education qualifications and training entry qualification are contributing factors to teacher attrition in public secondary schools in Tanzania. Malisa (2015) in his study assessed teachers' retention strategies in secondary schools in Tanzania and the study concluded that the success for teachers' retention depends upon strategies employed and how teachers perceive them. Hardman (2009) assessed on teacher education in Tanzania and the potential for closer links between pre-service and in-service teachers and Kyando (2010) assessed secondary school teacher attrition: response of stakeholders in Iringa Rural District and Municipality.

The aims of this study were to assess the influence of teachers' education qualifications on teacher attrition in the Public Secondary Schools in Kilimanjaro and Manyara Regions. Specifically, the study examined the influence of teachers' education qualification and teacher training entry qualification on teacher attrition. The paper was guided by Maslow Theory that based on esteem needs which were the main theories of the paper. Also, Herzberg's two factors theory that describes individual fulfillment of needs are highly dependent on individual satisfaction. The theories were divided into two categories namely; job satisfaction and job dissatisfaction. The satisfaction factors will cause employee retention while dissatisfaction will cause attrition. 


\section{Research Methods}

The study was conducted in Kilimanjaro and Manyara Regions. The Regions were chosen based on the following reasons; appreciable large number of public secondary schools they had 216 and 135 in Kilimanjaro and Manyara Regions respectively. The regions also had high students enrolment which leads to high teacherstudents Ratios (TSR) i.e. 97323 and 43234 (2015) with 1:53 and 1:51 TSR against are standard ratio of 1:40 in Kilimanjaro and Manyara Regions respectively. Likely, in the regions schools recorded to have inadequately staff classrooms with qualified teachers from the demand for teachers caused by a "revolving door" of teachers leaving their jobs "for reasons other than retirement (URT, 2016). In addition, these regions are vulnerable of younger teachers (20-30 years) leaving teaching, and the workload is heavy making some of the teachers unable to construct new examinations which led into administering past examinations to students (TSC,2016).

The study was carried out in three districts of each Region. The districts in Kilimanjaro Region were Rombo, Same and Hai, and that of Manyara Region were Mbulu, Babati and Hanang. Purposive sampling technique was used to sample six districts in both regions based on number of public secondary schools. According to Basic Education Statistics of public secondary schools, Rombo and Babati, Same, Hanang, Mbulu, and Hai districts had 41, 36, 33, 30 and 29 public secondary schools respectively (URT, 2016).

The study adopted a cross-sectional research design with mixed approaches by employing qualitative and quantitative strategies. Within the context of a cross sectional study, information is collected on the entire study population at a single point of time which can encompass a broad scale of information. The sample size for the study was 140 respondents determined by the formula $\mathrm{n}=\mathrm{N} /(1+\mathrm{Ne} 2)$ (Ryan, 2013): Whereby $\mathrm{n}, \mathrm{N}$, and e stand for a number of respondents, total population of the teachers and margin of error which is assumed to be $5 \%$ respectively. Out of the 140 respondents, 70 were in-service teachers and 70 respondents were teachers who had left teaching. The in-service teachers were obtained by using simple random sampling; in each district four schools were purposively chosen based on the number of teachers, and in each school 5 respondents were selected using lottery methods. The teachers who left teaching were obtained through snowball sampling.

The units of analysis for the study were in-service teachers and teachers who had left teaching from whom quantitative data were collected. Data was collected using questionnaires administration for both categories of respondents. However, telephone interview was used for teachers who had left teaching and were not physically reached during data collection. Quantitative data especially socio-demographic characteristics were analyzed using descriptive statistics such as frequency and percentages under the aid of Statistical Package for Social Sciences (SPSS) version 21.

In analyzing the influence of teacher's education qualifications and teacher's training entry qualifications on teacher attrition, binary logistic regression was used. Qualitative data from two Zonal Educational Quality Assurance Officers as key informants was obtained through face to face interviews.

The interviews were conducted to assess the extent of teacher's education qualifications and teacher training entry qualifications influences teacher attrition by using a checklist. The Zonal Educational Quality Assurance Officers provided in-depth data on annual teacher attrition. The data was analyzed thematically where information was grouped into themes and placed in the appropriate themes to support and counter argue the qualitative data.

\section{Findings and Discussion}

\subsection{The influence of teachers' education qualifications on teacher attrition}

Croasmum et al. (2007) and Voluntary Service Organization (2007) relate the teachers' level of education to the rate of attrition. Their conclusions agree partially with an earlier research by Johnson and Birkeland (2003) in respect to the relationship between the levels of education qualifications on attrition, whether a teacher received two-year teachers' college training or holders' of bachelor degree, was not related to retention. However, teachers who completed graduate studies or obtained Master's degrees continued to teach longer compared to those without Master Degree. This finding suggests that the professional level of training in education produces greater commitment to teaching hence less attrition. In assessing teachers' level of education qualifications on the influence of teacher attrition, six items were used and each of the items was assigned number which are zero and one. The items were analyzed using binary logistic regression.

Inferential statistics using binary logistic regression the findings show that the extent of prevalence of teacher education qualifications as a factor for teacher attrition from the response in Table 2 indicated that high level of mastering the subject, higher level of education and teachers Promotion lead into teacher attrition which is statistically significant $\mathrm{P}<0.1$ with overall percentage of 60 . Also the finding show that Omnibus Tests of Model Coefficients and Hosmer and Lemeshow Test were statistically significant $\mathrm{P}<0.004$ with Chi square value 19.222. All these tests justifies that the three variables under teacher's education qualifications influence teacher attrition. The findings revealed that teachers' education qualification influence teacher attrition in public secondary schools.

The Maslow hierarch of needs is in line with esteem needs by Maslow theory. In Maslow theory the 
likelihood is where as individual gets higher education over and above the previous, is more likely to find for respectable status different from the former. Nambundunga (2016) noted that the higher the level of education in teaching profession, the higher individual quitting the previous job searching for self-esteems.

The finding reveled that teachers who had left teaching due to higher education qualification in Kilimanjaro region, some of them joined private secondary schools and non government organizations which are presumably paying organizations.

These reasons have higher influence on teacher attrition than other variables. The teacher with such reasons has a revolving door to private schools or other related profession. The study revealed that two respondents in Manyara Region told the researcher that they had left teaching after mastering and experienced on how to stand in front of students in the classroom of which it is related to preaching profession, and therefore their intentions is to be a pastor.

On the other hand, in Kilimanjaro Region, four respondents left teaching and becomes the journalist the profession which is similar to teaching profession of which notes are prepared. The other five teachers joined private secondary schools. This was supported by the quotations from a key informant who was the educational quality assurance officer: he indicated that some of the teachers go on study leave but when they finish their studies, they do not come back with the argument that:

"It's unfortunate that most of the young and promising teachers do not come back to teach in the rural areas after finishing their studies. When a teacher goes on study leave, the next you hear that they have left the profession or they have transferred to private urban school."

Teachers felt that with improved qualifications they will become more qualified and marketable especially to private sector organizations that at the end they quit teaching and join other jobs. Also, another Educational Quality Assurance Officer from Babati District indicated that some teachers left teaching due to lack of promotional incentives with the argument that;

“...Because of limited career progression possibilities in the teaching field, teachers who are ambitious don't last long because they leave for the corporate careers where they have more possibilities of progression unlike in the teaching field.

Basing on that argument, the Educational Quality Assurance Officer agreed that the new graduates compared themselves with their counterparts who are working in the private sector where there are more chances of being promoted than in the public sector. The Educational Quality Assurance Officer admitted that the teaching profession had limited advancement or promotion opportunities: considering the large number of teachers and only a few managerial positions available in the profession. All two Educational Quality Assurance Officers agreed that despite limited promotion posts, few teachers who had advanced qualifications such as Master degrees and post-graduate diplomas in education were still teaching. This was supported by Educational Quality Assurance Officer from Rombo District with the argument that:

"...Those who continued teaching after acquiring their advanced degrees did so because they had not yet found an alternative job, otherwise only a very limited number of teachers furthered studies because of the love of the profession."

Basing on the arguments provided above, most of teachers pursue teaching profession as a prerequisite to go for other professions and high posts this leads to teacher attrition since teachers left teaching professional and go for other career after pursuing further studies.

The Herzberg's two factor theory describes teacher attrition as influenced by teacher's education qualifications where Herzberg's (1959) proposed that fulfillment of needs highly depends on individual satisfaction: in dissatisfaction attrition is inevitable. He divides the factors of need satisfaction into two categories namely factor that do not satisfy the individual needs but cause dissatisfaction exemplified by job benefits, working environment, job security, and salary: where all these factors is determined by increase level of education qualification for an employees. According to Nambundunga (2016) and Wang and dell (2002) argued that if satisfied factors are not met accordingly, they cause dissatisfaction which result in teacher attrition. However, if the factors are satisfied, teacher decides to stay in the profession.

\subsection{The Influence of Teacher Training Entry Qualification on teacher attrition}

In analyzing teacher training entry qualifications on teacher attrition, the researcher measured four items in the matrix using binary logistic regression. The findings show that the use of fake certificate scored $66.4 \%$ can lead into teacher attrition indicated by- 1.046 which is slightly statistically significant $\mathrm{P}<0.260$. This implies that the presence of student teachers in teacher training institutions with fake certificate can influence teacher attrition once the government caught them which will into dismissal. The performance of advanced secondary education examinations also scored $66.4 \%$ can predict teacher attrition by -1.157 which is slightly statistically significant $\mathrm{P}<0.20$ while Upgrading from certificate to diploma level scored $48.6 \%$.

This implies that the extent of prevalence of teacher training entry qualification on teacher attrition can be influenced by the three variables as stipulated above by percentage wise. If the performance of advanced 
secondary education examinations is good, an individual is likely to join teacher training institution which in turn left the previous job if he/she was a teacher with low education qualification. This is applied to those teachers who provided with teaching license. On the issue of Upgrading from certificate to diploma level, an individual after been upgraded from lower level of education to upper level he/she might quit teaching public secondary schools and join private secondary schools, that is attrition proxy public secondary schools. On the use of fake certificate to join teacher training institution, an individual can join the college, later if the government vetting their civil servants and if that individual happened to be caught like what happened in Tanzania 2017 such teacher will be out of the educational system due to dismissal from the work place which considered as part of teacher attrition Respondents responded on these three aspects positively and the findings analyzed using binary logistic regression proved statistically significant under Omnibus Tests of Model Coefficients, Hosmer and Lemeshow Test with Chi square value of 4.652 which is significant $\mathrm{p}<0.1$ while the overall percentage is 56.4 . This indicates that entry qualification in teacher training institutions influence teacher attrition in public secondary schools by $56.4 \%$.

In both teachers' categories they scored above $50 \%$ and it revealed that teacher training entry qualification were similar and are in accordance to government criteria pertaining to teacher training at different levels (Nzalayaimisi, 1993).

The study found that teachers with diploma in education were slightly lower attrition compared to those with high education qualification. This implies that employment to teach in public secondary schools is best and suitable for those with at least bachelor degree in education. Yet, the study finding suggests that with regarded to teacher attrition, the level of teacher education qualification is cutting across to each group though with slight difference. Such a difference could be attributed to the salary scheme of teachers' of public secondary schools between graduate and non graduate teachers (MoEVT, 2001), thus all could be dissatisfied and quit teaching in public secondary schools. According to Malisa (2015), some people focus on teaching profession as a last resort activity; such a feeling cause influx of employees in the teaching professional who is not committed to stay in the profession leads into teacher attrition due to reasons other than retirement.

Other variable were not statistically significant. This implies that from the opinion of the respondents; teacher entry qualification in teacher training institutions has an influence on teacher attrition. However, the results from responses of in-service teachers using non parametric tests using independent sample t-test indicated $\mathrm{t}$ score of 105.74. The result indicated that all variables were statistically significant with a p-value of 0.000 . This implies that from the opinions of the teachers who had left the teaching; teacher training entry qualification in teacher training institutions contributes to teacher attrition.

According to Nambundunga (2016), if teachers do not have their basic needs fulfilled, they will seek other opportunities. In many countries, the teaching profession provides people with a secure and stable job. Many people have joined the teaching profession because of security and stability as Maslow termed them as esteem needs (Dembo, 2014). On the need for belonging, Steyn and Van-Niekerk (2012) agrees with Maslow theory that a teacher need to know and understand teaching and its responsibilities before joining teaching courses and at the end join the professional, if that understanding are not satisfied and supported the teacher would not feel comfortable to remain in the teaching profession.

Zonal Educational Quality Assurance Officers stated that some teachers joined the teaching profession as a last resort in being employed by the government as an alternative after failing to be employed in lucrative employment sectors offered by local and international private organizations. One of them said:

"The Ministry of Education, Science and Technology needs therefore to scrutinize applicants of teacher education training rather than depend on the passes one gets in the National Examinations that are used to admit a person in a teacher education program which at the end will make the applicant be a qualified teacher but not a teacher indeed."

Another added that:

"The other reason as to why some teachers quit the teaching profession in secondary schools is that some private teacher training colleges lower the entry qualification in order to attract more admission of students to teacher education programs. Any individual who missed the government criteria for admission in government Teacher Training Colleges run to these institutions and get admitted. At the end, one graduates but not qualified for the teaching profession"

Basing on the argument rose above, it implies that some private teachers training institutions admits teachers with low entry qualifications, that at the end leads to teacher attrition. This is due to having graduates that are not competent on the teaching subjects. Zonal Educational Quality Assurance Officers indicated that some teachers joined the teaching profession as a last resort and they often used teaching as a bridge to other lucrative professions in the parastatals and private sector. The Zonal Educational Quality Assurance Officers felt that the entry requirements for degrees and diploma teachers were the most attainable, such that those who failed to qualify for other training programmes ended up taking teaching as a last resort.

Zonal Educational Quality Assurance Officers lamented that such people would not stay long in the 
profession but would leave as soon as they obtained other jobs. They emphasized that such teachers left the profession within the first five years of entering the profession, which resulted in an unreasonably attrition of teachers in the early years of training. Researcher found that teacher training entry qualification in the educational institutions must have common and clear criteria in order to stop the hangover that teaching is a common professional and therefore those who think that teaching activities is a last resort will never get a chance to call that.

This is in line with government policy 2014 through Ministry of Education, Science and Technology stipulated that the entry qualification for certificate level candidate must have four passed subject at grade "D", to join university qualified candidate must have Grade Point Average of 3.0 (MoEVT, 2007). These are stipulated by the government through Ministry host in order to add value education quality.

\section{Conclusion}

The study concludes that teacher education qualifications and teacher training entry qualifications influences teacher attrition for those who entered in the teachers' education programmes than those who went into the programmes with weak qualification though the programmes demanded all teachers in different teacher education programmes to have good entry qualifications. The study recommends to the Presidents' Office Regional Administration and Local Government (PORALG) that teacher education qualification in the educational institutions in the country must have common and clear criteria of employment in order to stop the hangover that teaching is a common professional.

Also teachers who graduated from colleges that used government entry qualifications, some left teaching by joining to other lucrative jobs easily compared to those who graduated from private colleges which are assumed to have weak candidates. On the issue of competent graduate teacher, one could leave teaching due to availability of private schools which are paid better than public owned schools. The study recommends to the government that salary increment and promotions should be executed to those who completed their studies.

On teacher training entry qualification as a factor for teacher attrition the study recommend to Presidents' Office Regional Administration and Local Government (PORALG); Enrolment of student teachers' to the teacher training institution (s) should adhere to public entry qualification regardless of the institution ownership as it has applied in other public sectors in order to come up with committed teachers and establishment of alternative certification programme which is partly attracting more talented candidates to the teaching profession and partly in reaction to current and anticipated shortage of teachers in Tanzania.

\section{References}

Asare, E.O, Mereku, D.K Anamua-Mensah, J and Oduro, G.K.T. (2012). In-Service Teacher Education Study in Sub-Saharan Africa: The Case of Ghana. UNESCO-IICBA, Addis Ababa \& Commonwealth Secretariat, London. 35pp.

Barnett, B., Kenhoo, M., Menarch, U. and Washington, E. (2008). Creating sustainable teacher resilience among urban teacher residency: A new way to recruit, prepare and retain effective teachers in high needs districts. Aspen Institute: Washington, D.C, 23-28pp.

Croasmum, J., Hampton, D., and Herrmann, S. (2007). Is Time running out? Exceptional Children, 6 (7): 549567.

Darling-Hammond, L. (2003). Teacher learning that supports student learning. Educational Leadership, 55 (5): 6-11.

Dembo, M. (2014). Applying educational psychology. California: Longman. Educational Leadership, 60 (8): 24-38.

Futernick, K. (2007). A possible dream: retaining California teachers so that all students can learn. California: California State University.

Hahs-Vaughn, D. L., and Scherff, L. (2008). Beginning English teacher attrition, mobility, and retention. Journal of Experimental Education, 77(4): 173-208

Hardman, F. (2009). A Review of Teacher Education in Tanzania and the potential for closer links between PRESET and INSET. A report produced in support to the Ministry of Education and Vocational Training (MoEVT) for the Development of an INSET strategy and development plan linked to the Teacher Development and Management Strategy (TDMS) 2008-2013. The University of York. 452pp.

Herzberg, F. (1959). Motivation to work. John and Wiley. New York. The Journal of Psychology, 120(6): 613626.

Hobson,J. A, Tracey, L., and Malderez, A. (2014). Navigating Initial Teacher Training: Becoming a Teacher. Routledge. 26 pp.

Huling-Austin, L. (2006). Teacher induction programs and internship. In W. R. Houston (Ed.). Handbook of research on teachers' education. , New York. 86pp.

Ingersoll, R. and Strong, M. (2011). The impact of education and mentoring programme for beginning teachers: 
A critical review of the research. Review of Education Research, 81(2): 201-233

Ingersoll, R, Merrill, L. and May, H. (2014). What Are the Effects of Teacher Education and Preparation on Beginning Teacher Attrition? Consortium for Policy Research in education. University of Pennsylvania. $33 \mathrm{pp}$.

Ingersoll, R., and Smith, T. (2007). The wrong solution to the teachers' shortage. Educational Leadership, 3(3):45-56.

Ingersoll, R., Perda, D and May, H. (2014). An analysis of the effects of teacher qualifications on student achievement in the core subjects in Grade 8 using the 2003 NAEP. Manuscript in preparation examinations. Journal of Evaluation and The Health Professions, 17(2): 133-159.

Johnson, S. M. and Birkeland, G. (2003). Finders and keepers: Helping new teachers survive and thrive in our schools, CA. Jossey-Bass: San Francisco, 76pp.

Koontz H and Weilrich H (2005) .Essentials of Management. Mc Graw. Hill: New Delhi.234pp.

Kyando, S. N. (2010). Secondary school teacher attrition: Responses of stake holders in Iringa Rural and Municipality. Dissertation for Award of M.A Degree at Open University of Tanzania: Tanzania, 142pp.

Lambert, S. (2004). Teachers pay and conditions: An assessment of recent trends in Africa. Background paper prepare for the education for all global monitoring report 2005. The quality imperative. UNESCO: Paris, $314 \mathrm{pp}$.

Loock, C., Grobler, B., and Mestry, R. (2006). Human resource management in education. Rebalancing the scale. Educational Research Association Journal, 2(4):45-56.

Malisa, A.S. (2015). Teachers' Retention Strategies in Secondary Schools in Tanzania: A Case of Hanang District Council. Dissertation for Award of M.E at Open University of Tanzania: Tanzania, 91pp.

Ministry of Education and Vocational Training. (2007). Teacher Education Development and Management Strategy- 2007/08 to 2010/11. MoEVT: Dar es Salaam. 57pp.

Ministry of Education and Vocational Training. (2001). Teacher Training Development. National Review. MoEVT: Dar es Salaam. 24pp.

Ministry of Education and Vocational Training. (2009). Educational For ALL Report for Tanzania Mainland. Education for all 2015 National Review. MoEVT: Dar es Salaam. 76pp.

Muhammad, J and Maka, F. (2015). In-service Teacher Education in Sub-Saharan Africa: A synthesis Report. The Common Wealth: Nairobi. 120pp.

Nambundunga, M. (2016). Factors that Influence Teacher Attrition in Secondary Schools in the Omusati Education Region. Dissertation for Award of M.E Degree at Namibia University: Namibia.102pp.

Nzalayaimisi, G.K. (1993). A Study of Tutors, Students and Curriculum in four colleges preparing Primary School Teachers in Tanzania. Thesis for Award of PhD Degree at The Ohio State University, Columbus, United States of America, 232pp.

Preston, A. (2000). Finders and keepers: Helping new teachers survive and thrive in our schools. The project on the next generation of teachers. Jossey-Bass: San Francisco, 124pp.

Ryan, T. (2013). Sample Size Determination and Power. John Wiley and Sons. Washington DC. 34pp.

Salahu, M.L and Aminu, A.W. (2010). History education for national development. Journal of Educational Studies, 2(3): 223-232.

Steyn, K. and Van Niekerk, T. (2012). Human efficacy in social Psychology. McMillan: Chicago, 129pp.

Teacher Service Commission (TSC). (2016). Teachers penalized for various disciplinary offences in the country. Government Printing Office: Dar es Salaam. 47pp.

United Republic of Tanzania. (2016). President's Office Regional Administration and Local Government, Basic Education Statistics (BEST). Government Printing Office: Dar es Salaam, 276pp.

United States of America Departmental of Education. (2012). Teacher attrition and mobility: Results from the 2004 -2005 teacher follow up survey: Departmental of Education: California, 162pp.

Voluntary Service Organisation. (2007). Teachers speak out. A policy research report on motivation and perception of their profession in Malawi. MoHSS: Lusaka: 84pp.

Wang, J., and Odell, S. (2002). Mentored learning to teach according to standards based on reform: A critical review of educational research. Sage Journals, 72(3): 481-456.

Wilson, S. M., Bell, C., Galosy, J. A. and Shouse, A W. (2014). Them that's got shall get": Understanding teacher recruitment, induction, and retention. In M.M. Smylie, and D. Miretzky (Eds.), Developing the teacher workforce: $103^{\text {rd }}$ year book of the National Society for the Education (Vol. 103 part 1). University of Chicago Press. Chicago. 145-179 pp.

World Bank Education Reforms. (2007). Education and teacher attrition in the SADC Regions. World Bank Office: Cape Town. 48pp. 